\title{
Ecological Data of Travassosnema travassosi travassosi (Dracunculoidea: Guyanemidae) from the Humour of the Eyes of Acestrorhynchus lacustris from Tibagi River, Paraná, Brazil
}

\section{Ângela Teresa Silva-Souza ${ }^{+}$, Aurélia Saraiva*}

Departamento de Biologia Animal e Vegetal, CCB, Universidade Estadual de Londrina, Caixa Postal 6001, 86051-990 Londrina, PR, Brasil *Departamento de Zoologia e Antropologia, Faculdade de Ciências, Universidade do Porto, Porto, Portugal

Data obtained between 1990 and 1995 provide, for the first time, ecological information of the parasitic nematode Travassosnema travassosi travassosi Costa, Moreira \& Oliveira, 1991 from Acestrorhynchus lacustris (Characiformes: Acestrorhynchidae) collected in the Tibagi River, Sertanópolis, Paraná, Brazil. These nematode occurred with low prevalences (7.7\% to $28.6 \%$ ) and intensities (1 to 3) during almost the whole year. The observation of mature females throughout the year indicate that liberation of larvae can occur during all the year around. This is the first report on the occurrence of $\mathrm{T}$. travassosi travassosi inside the eyes. These nematodes were mostly located in humour of the eyes (87\% of cases), being less frequently detected in tissues behind the eyes (13\% of cases).

Key words: Travassosnema travassosi travassosi - Nematoda - parasites - Acestrorhynchus lacustris - Tibagi River Paraná - Brazil

The genus Travassosnema Costa Moreira \& Oliveira 1991 (Dracunculoidea: Guyanemidae) is represented by medium sized nematodes with a rounded cephalic end, without a buccal capsule and with the oesophagus divided into an anterior muscular and a posterior glandular portions. The posterior glandular portion of oesophagus is provided with a long dorsal appendix extending posteriorly, a feature that makes this genus easily distinguishable from the genus Guyanema Petter, 1974 (Costa et al. 1991, Moravec 1998).

Two subspecies of the only species $T$. travassosi Costa Moreira \& Oliveira, 1991 are known to occur in South American freshwater fishes, Acestrorhynchus lacustris Reinhardt, 1874 (Characiformes: Acestrorhynchidae) being the only known host of these parasites (Moravec 1998, Vicente \& Pinto 1999). T. travassosi travassosi Costa Moreira \& Oliveira, 1991 was detected in the tissues behind the eyes (orbits) from fishes from the Três Marias Reservoir on the São Francisco River, State of Minas Gerais, Brazil (Costa et al. 1991), while T. travassosi paranaensis Moravec Kohn \& Fernandes, 1993 was detected in the abdominal cavity from fishes of the Paraná River near Guaíra, Brazil (Moravec et al. 1993). No data have been published on the prevalence and the intensity of infection of these nematodes.

During a study of helminth parasites of the eyes of A. lacustris conducted between 1990 and 1995 in the Tibagi River, Paraná, Brazil, the dracunculoid nematode $T$. travassosi travassosi was observed. Data related to ecological indexes of prevalence and intensity of infection of these parasites are evaluated in this paper.

\section{MATERIALS AND METHODS}

Nematodes were collected from both the orbits and humour of the eyes of $A$. lacustris caught by waiting nets

${ }^{+}$Corresponding author. Fax: +55-43-371.4207. E-mail: ateresa@uel.br

Received 28 March 2001

Accepted 13 September 2001 in Tibagi River, Sertanópolis, Paraná, Brazil near the confluence to Paranapanema River ( $22^{\circ} 30^{\prime} \mathrm{S}$ and $\left.51^{\circ} 00^{\prime} \mathrm{W}\right)$. The study area became a semi-lotic system after the construction of Capivara dam, on the Paranapanema River, in 1975. Fish samples were collected between April 1990 and February 1991 ( $\mathrm{n}=51$; body length: $14.3-27.6 \mathrm{~cm})$, August 1992 and July $1993(\mathrm{n}=122$; body length: $10.6-27.5 \mathrm{~cm})$ and April 1994 and May 1995 ( $n=46$; body length: 10.4 $23.9 \mathrm{~cm}$ ). Samples were obtained occasionally during these periods excluding from August 1992 to July 1993 when samples were obtained monthly.

Nematodes were fixed and stored in $70 \%$ ethanol and cleared in glycerine for examination.

\section{RESULTS}

The prevalence of T. travassosi travassosi found in A. lacustris is shown in the Table. The intensity of infection was usually low (1 to 3 specimens) but, in December 1992, 13 and 26 nematodes were detected in the humour of the eyes of two hosts. In fact, T. travassosi travassosi was mostly located inside the eyes $(87 \%)$ in the humours and, in the majority of cases, both eyes were infected (Fig. 1). Less frequently (13\%), the nematodes were found in the tissues behind the eyes, i.e. orbits.

The prevalence in the samples carried out monthly between August 1992 and July 1993 is shown in Fig. 2. These results indicate that specimens of $T$. travassosi travassosi occur in A. lacustris during almost all the year without a marked seasonal cycle. Only $2 \%$ of nematode specimens were males, and mature females with uterus

\section{TABLE}

Prevalence of Travassosnema travassosi travassosi in Acestrorhynchus lacustris from Tibagi River, Sertanópolis, Paraná, Brazil

\begin{tabular}{lcc}
\hline Date & $\mathrm{Ni} / \mathrm{Ne}$ & Prevalence (\%) \\
\hline April 1990 to February 1991 & $2 / 51$ & 3.9 \\
August 1992 to July 1993 & $18 / 122$ & 14.8 \\
April 1994 to May 1995 & $3 / 46$ & 6.5 \\
\hline
\end{tabular}

$\mathrm{Ni}$ : number of specimens infected; Ne: number of specimens examined 
containing larvae were observed throughout the year, indicating that the liberation of larvae could occur in this locality during all the year. Excluding these small larvae (probably first-stage larvae), other larval stages were never observed in the eyes.

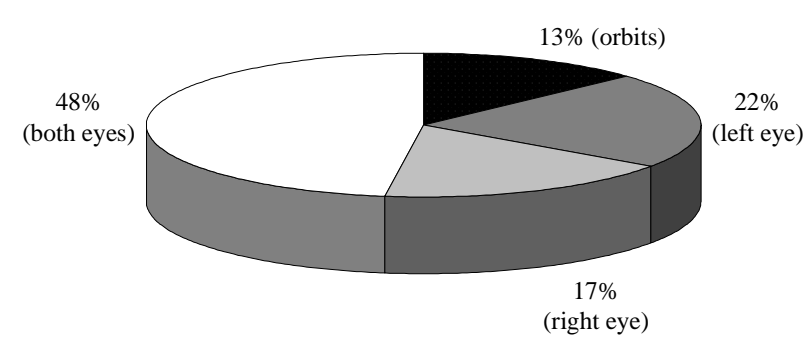

Fig. 1: percentage of specimens of Travassosnema travassosi travassosi detected in the orbits and in the humour of eyes (just in right, just in left or in both eyes) of Acestrorhynchus lacustris from the Tibagi River, Sertanópolis, Paraná, Brazil.

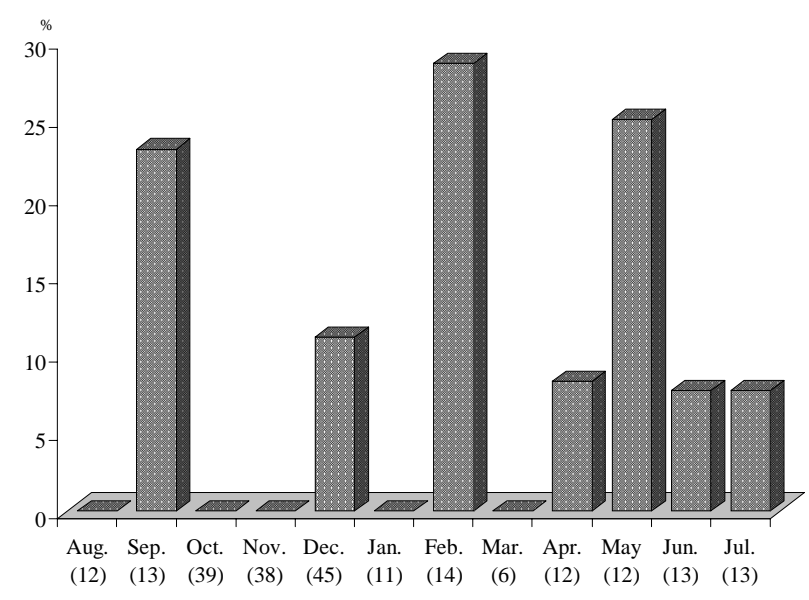

Fig. 2: monthly values of the prevalence of Travassosnema travassosi travassosi in Acestrorhynchus lacustris collected between August 1992 and July 1993 in the Tibagi River, Sertanópolis, Paraná, Brazil. Sample sizes in brackets

\section{DISCUSSION}

This is the first report on the occurrence of T. travassosi travassosi in the humours of the eyes. This observation seems to be important because helminth eyes parasites usually cause opacity of the eye lenses and even blindness, symptoms that usually decrease the growth rates due to fish difficulties to localize food and also reduction of the fish population due to smaller fish ability to escape to predators.

In the present study, we observed that the prevalence and the intensity of infection were much higher inside the eyes than in the orbits where these nematodes were first detected. These parasites were present, in the study area, usually with low values of prevalence and intensity of infection during almost the whole year.

These parasites, both males and mature females, were located in orbits and humours of the eyes in the examined specimens of A. lacustris. However, it is possible that, as occurs with other dracunculoids, other organs can also be infected by T. travassosi travassosi. For this reason a detailed helminthological examination of the other specimens of A. lacustris from Tibagi River will be interesting in the future.
The life cycle of T. travassosi travassosi undoubtedly involves an intermediate host. The family Guyanemidae shows some affinities with the closely related dracunculoid families Skrjabillanidae and Daniconematidae (Moravec \& Køie 1987, Molnár \& Moravec 1994). In skrjabillanids, the first-stage larvae released from the viviparous nematodes are taken up by the intermediate host, hematophagous branchiurids (Argulus spp.), and third-stage larvae are inoculated by these invertebrates into the vertebrate definitive host (Moravec 1994, 1998, Molnár \& Székely 1998, Moravec et al. 1998). According to Molnár and Moravec (1994), Molnár (1997) and Moravec et al. (1999), daniconematids seem to have, because of the morphological similarity of these nematodes, a life cycle very similar to skrjabillanids, i.e. haematophagous branchiurids could also serve as intermediate hosts of these nematodes. For the same reason it seems that we could speculate the same for guyanemids. This hypothesis is corroborated by Moravec (1998) who stated that probably some blood-sucking invertebrate ectoparasites probably serve as intermediate hosts of $T$. travassosi travassosi. The elucidation of the life cycle of these nematodes requires a detailed study including the identification of the blood-sucking ectoparasites that occur in the study area and the search for larval stages of these nematodes in scales, skin and subcutaneous tissues of A. lacustris.

\section{REFERENCES}

Costa HMA, Moreira NIB, Oliveira CL 1991. Travassosnema gen. n. with the description of T. travassosi sp. n. (Dracunculoidea, Guyanemidae) parasite of Acestrorhynchus lacustris Reinhardt, 1874 (Characidae) from Três Marias Reservoir, MG, Brazil. Mem Inst Oswaldo Cruz 86: 437439.

Molnár K 1997. New data on the location of Daniconema anguillae (Nematoda: Dracunculoidea) adult stages in eels. Bull Eur Ass Fish Pathol 17: 96-98.

Molnár K, Moravec F 1994. Third-stage larvae of Daniconema anguillae (Nematoda: Dracunculoidea) in the subcutaneous tissue of eel Anguilla anguilla. Folia Parasitol 41: 215-219.

Molnár K, Székely Cs 1998. Ocurrence of skrjabillanid nematodes in fishes of Hungary and in the intermediate host, Argulus foliaceus L. Acta Vet Hungarica 46: 451-463.

Moravec F 1994. Parasitic Nematodes of Freshwater Fishes of Europe, Academia and Kluwer Acad. Publishers, Prague and Dordrecht, Boston, London, 473 pp.

Moravec F 1998. Nematodes of Freshwater Fishes of the Neotropical Region, Academia, Prague, 464 pp.

Moravec F, Køie M 1987. Daniconema anguillae gen. et sp. n., a new nematode of a new family Daniconematidae fam. $\mathrm{n}$. parasitic in European eels. Folia Parasitol 34: 335-340.

Moravec F, Kohn A, Fernandes BMM 1993. Travassosnema travassosi paranaensis subsp. $\mathrm{n}$. and first description of the female of Guyanema raphiodoni Moravec, Kohn and Fernandes, 1993 (Nematoda: Guyanemidae), dracunculoid parasites of characid fishes in Brazil. Ann Parasitol Hum Comp 68: 229-233.

Moravec F, Molnár K, Székely C 1998. Lucionema balatonense gen. et sp. n., a new nematode of a new family Lucionematidae fam. n. (Dracunculoidea) from the swimbladder of the European pikeperch, Stizostedion lucioperca (Pisces). Folia Parasitol 45: 57-61.

Moravec F, Vidal-Martínez V, Aguirre-Macedo L 1999. Branchiurids (Argulus) as intermediate hosts of the daniconematid nematode Mexiconema cichlasomae. Folia Parasitol 46: 79.

Vicente JJ, Pinto RM 1999. Nematóides do Brasil. Nematóides de peixes. Atualização: 1985-1998. Revta Bras Zool 16: 561610. 